Journal of Teacher Education for Sustainability, vol. 22, no. 2, pp. 153-170, 2020

\title{
What Factors Matter for the Sustainable Professional Development of Teachers? Analysis from Four Countries
}

\author{
Agne Brandisauskiene, Jurate Cesnaviciene, \\ Rita Miciuliene and Lina Kaminskiene \\ Vytautas Magnus University, Kaunas, Lithuania
}

\begin{abstract}
In the $21^{\text {st }}$ century, teachers' learning is viewed through the lens of sustainable development as a holistic, transformative and collaborative learning process. Acknowledging that teacher professional development is a prerequisite for educational quality, it becomes necessary to look for professional development factors that could be relevant to sustainable professional development. The article explores factors of sustainable professional development of teachers based on data of TALIS 2018 from four Baltic countries (Estonia, Finland, Latvia, and Lithuania). The study also discusses distinct characteristics of teacher professional development in the analyzed countries. Although traditional forms and methods of professional development still prevail in all countries, teachers also learn through active cooperation. Finnish teachers, more often than teachers in the other countries, worked in teams and shared material, knowledge, etc. with each other; Estonian teachers, more so than teachers in the other countries, took part in long-term training; Latvian teachers were more likely than teachers in the other countries to observe other teachers' classes and provide feedback. Lithuanian teachers were perhaps the most active in terms of learning, but young teachers with fewer years of service were more likely to engage in long-term and collaborative activities. Finally, the implications for further research are discussed.
\end{abstract}

Key words: teacher learning, sustainable professional development, professional development factors, collaborative learning, TALIS

\section{Introduction}

As economic, environmental and globalisation challenges constantly arise, sustainable development is seen as a key factor in the development of society in the $21^{\text {st }}$ century (United Nations, 2015). The guidelines for achieving the fourth goal (UNESCO, 2015) highlight the unique role of education in implementing the sustainable development goals and ensuring economic, environmental and social sustainability. Education for Sustainable Development at all levels of the educational system is recognized for its 
essential goal of developing the attitude and ability of all members of society to act responsibly, creating a more sustainable world and tackling sustainability-related problems (UNESCO International Bureau of Education, 2015; UNESCO, 2017). The global context of COVID-19 compelled the educational community to return to sustainable education goals (United Nations, 2020; UNESCO, 2020). In light of The 2030 Agenda for Sustainable Development, the International Commission on the Futures of Education (2020) proposed nine ideas: to strengthen education as a common good; to expand the definition of the right to education, addressing the importance of connectivity and access; to value the teaching profession and teacher collaboration; to promote student, youth and children's participation in education, viewing them as co-constructors of education; to enhance and protect the social spaces provided by schools, exploring potentials for a diverse learning environment; to make free and open source technologies available to teachers and students; to ensure scientific literacy within the curriculum; to protect domestic and international financing of public education; and to advance global solidarity to end current levels of inequality.

Education focused on the principles of sustainable development helps teachers not only understand better what the fundamental principles of education of the future are, but also see the content of education as an opportunity to provide learners with competences and knowledge that enable them to act in a world of exponential and systemic changes. For this reason, teacher education and professional development must be refocused on the needs of sustainability-specific educational policy, curricula and practices. This means that in order to achieve sustainable educational goals, teachers need to acquire competences such as critical thinking, collaborative skills, problem-solving, decisionmaking, and others that encourage involvement and ongoing research (Iliško, Ignatjeva, \& Mičule, 2010; Wells, 2013).

In the scientific literature, sustainable professional development of teachers is linked to effective learning (Villegas-Reimers, 2003), which encourages the accumulation of teachers' acquired knowledge, based on local knowledge and experience. Sustainable professional development of teachers is also based on research; it enables teachers to act when solving problems, strengthens professional networks, and encourages the formation of a vocational learning community where teachers share, cooperate, understand and support each other, which allows for systemic educational changes to be achieved not only in the institutional but also in the country's educational context (VillegasReimers, 2003).

The modern professional development of teachers is focused on the fact that it would be meaningful not only for the teachers themselves when developing curricula, testing new methods, carrying out evaluation, but that the benefits of their professional development would be obvious to learners as well (Meesuk, Sramoon, \& Wongrugsa, 2020). Self-directed teacher improvement is encouraged, abandoning traditional professional development models, which were oriented towards teachers as recipients of knowledge rather than active creators of knowledge (Makovec, 2018; Sumaryanta et al., 2019).

In addition, according to Hargreaves and Fink (2006), the educational system itself can borrow some very important postulates from the sustainable development movement: to see things from a long-term perspective, in pursuit of change not to fear decisions that require courage, and to have patience while awaiting results. Finally, the learning process in which the sustainable development goals are being pursued must in its particu- 
larities be holistic and transformational, supporting self-directed learning, participation and collaboration, orientation to problems, interdisciplinarity and transdisciplinarity, and the linking of formal and informal learning (UNESCO, 2017). In our view, such learning must become a key prerequisite for the professional growth of teachers, since such professional development is the basis for the quality of education (Thurlings $\&$ den Brok, 2017).

In terms of the quality of education, the issue of school learners' achievements is central. While Darling-Hammond with colleagues (Darling-Hammond, Hyler, \& Gardner, 2017) emphasize that effective professional development changes the quality of teacher education and improves student performance, there is little valid and scientifically grounded evidence of a clear link between teachers' professional development and student achievement (Guskey, 2009; Fletcher-Wood \& Zuccollo, 2020; Sims \& Fletcher-Wood, 2020). Nevertheless, countries are often compared with each other on the basis of various educational quality parameters and student achievements. Finland is recognized as among the countries having the highest-quality educational systems. Many international studies testify to the success of the Estonian educational system. Meanwhile, the quality of the educational systems in Latvia and Lithuania not only lags significantly behind their neighbors, but often does not exceed the EU average. When comparing the abovementioned geographically close countries, it is natural that we want to look more closely at the similarities and differences of teacher professional development in order to find logical arguments for the ongoing debate on the quality of national educational systems. This article therefore raises the following problematic questions: What teacher professional development factors are specific to the Baltic countries and what characteristics of teacher professional development factors are specific to each of these countries? In search of answers to these questions, the article compares the professional development of teachers in Finland, Estonia, Latvia and Lithuania based on the 2018 international study "Teaching and Learning International Survey" (TALIS).

\section{Factors of the Process of Sustainable Professional Development of Teachers}

Almost two decades ago, Guskey and Sparks (2002) suggested that the quality of teacher professional development could be determined by various groups of factors, but three would have the strongest and direct impact: content characteristics (knowledge and skills), process variables (types of professional development activities, forms and methods of how the activity is carried out) and context characteristics (the system and culture itself). In recent scientific analyses, although the factors have been named differently, the most important ones remain the same: quality content (subject-specific and pedagogical content knowledge), learning design and implementation (a range of opportunities for active and varied continuing professional development, collaborative learning experiences and job-embedded learning), support and sustainability (sufficient time and duration of continuing professional development, availability of resources, and supportive and engaged leadership in schools and at the system level) (Campbell, 2019). This study will focus on the professional development process factors that, as recognized in recent studies, are the most effective, i.e., long-term, systematic, contextualized, taking place at workplaces, in local learning communities (Hargreaves \& Fullan, 2012; Postholm, 2012; Li \& Dervin, 2018). 
Collaborative learning experiences can be described as one of the factors of effective and sustainable teacher professional development (Campbell, 2019), which is typical of educational systems demonstrating a high level of learning outcomes for school learners (Jensen et al., 2016). According to Li and Dervin (2018), in order to enable teachers to exchange best practices, it is important to find out what the individual needs of each teacher are and what teachers can learn from each other, based on their professional practice or subsequent experience. Although a teacher's daily life has no lack of individual work and individual reflection, it makes sense for teachers to reflect together on their teaching practices in order to improve them (Postholm, 2012). It is becoming apparent that teachers' collective collaborative learning strengthens the professional development of teachers (Postholm, 2016), improves teaching inquiry (Volkinsteine \& Namsone, 2016), contributes to the development of a new collaborative culture among teachers (Silova et al., 2010), and is also associated with higher job satisfaction and teacher selfefficacy (OECD, 2020). According to Hargreaves and Fullan (2012), teachers improve at the workplace by exchanging ideas, cooperating, participating in such activities as study groups, research, etc. Such professional learning communities can be effective because they promote sharing of insights into problems and foster mutual collective responsibility for interventions and improvements that directly affect school learners' learning. However, the same authors observe that learning together may also be ineffective, when teachers simply discuss and share ideas and practices, not seeking to explore or evaluate them, without any clear link with the improvement of practice (Hargreaves $\&$ Fullan, 2012). We believe that this emphasis on the essence and expediency of cooperation is very important and explains why some researchers argue that cooperation among teachers cannot be recognized unambiguously as an effective part of their professional development (Sims \& Fletcher-Wood, 2020). Cordingley clearly defines a necessary condition of effective collaborative learning: "Professional learning conversations and collaboration need to be rooted in experimentation with new approaches to be linked with success" (Cordingley, 2019, p. 140). It should be noted that cooperation among teachers as one of the essential elements of professional development is sought in many countries. For example, Darling-Hammond, Hyler and Gardner (2017), reviewing the professional development experience of teachers in different countries, observe that such countries (e.g., Singapore, the United Kingdom, Australia, Canada) aim to provide teachers with opportunities to share their teaching, mentoring, educational content (curriculum) and leadership experiences, and to learn from each other.

Weston and Hindley (2019), performing a systematic analysis of various reviews in 2015-2019, identified one of the most important factors of effective professional development as iterative process, with opportunities to apply learning in real practice. This process of professional development takes place, e.g., in the context of the school, by clearly linking teacher professional development opportunities to their practical classroom experience. In this way, the role of teachers as active learners becomes more apparent. They can engage in learning, evaluation, monitoring and reflection processes, use authentic artifacts, interactive activities and other strategies for deeply integrated, highly contextual professional learning (Darling-Hammond, Hyler, \& Gardner, 2017). Such training may benefit from operational research. Research performed by Iliško, Ignatjeva and Mičule (2010) confirmed that when teachers perform research with the purpose of improving their educational practice, they gain new and better ways of 
seeing their classroom practice, and see new perspectives in the context in which they operate. Thus, teachers become active decision makers about what concerns their work (Iliško, Ignatjeva, \& Mičule, 2010). According to Harrison and co-authors (Harrison et al., 2006), effective teacher professional development needs to enable teachers to reflect on and learn about new practices and how they can evolve or be modified from the existing classroom practice.

The length of time for learning becomes one of the most controversial factors in discussing the effectiveness of teacher professional development. On the one hand, it is obvious that professional development itself is an ongoing, long-term process, since, as already mentioned, the changes that take place constantly put new demands on teachers to develop new competences (e.g., require leadership competence, preparation and team work opportunities, interdisciplinary skills, etc.). Teachers must also have sufficient time to practice, implement and reflect on new strategies to facilitate changes in their practical activities (Darling-Hammond, Hyler, \& Gardner, 2017). Therefore, the process of professional development itself is long-term and encompasses ongoing purposeful and systematic opportunities and experiences to stimulate one's professional growth. However, the duration of the professional development learning activity is not unambiguously clear. Sims and Fletcher-Wood (2020) argue that there is a lack of evidence to show that long-term programs make professional training effective, while Basma and Savage (2018) indicate that short-term, but high-quality, teacher learning is effective.

The analysis of scientific literature certainly makes it possible to create a fairly wide range of factors for sustainable professional development, but in our research we have identified those which, in today's situation, are gaining ever stronger weight for sustainable professional development of educators (Wells, 2013; Weston \& Hindley, 2019; Sims \& Fletcher-Wood, 2020). In this article, we present an analysis of the factors of the process of professional development of teachers in Lithuania, Latvia, Estonia and Finland, such as mutual cooperation, place of learning and time, and their characteristics, based on the data of the TALIS 2018. Some limitations of this investigation are also to be noted. Firstly, the TALIS database is very important due to the open access to data of different countries, but in this case it does not allow all the factors of sustainable professional development to be explored. Secondly, the area of teacher professional development is still lacking in theoretical conceptual models and mechanisms (Weston \& Hindley, 2019), teachers learn and improve in different ways, so it is difficult to unambiguously describe the factors of effective teacher professional development and their characteristics.

\section{Method}

\section{Study Participants}

The TALIS 2018 data set was downloaded from http:/www.oecd.org/education/ talis/talis-2018-data.htm. The distribution of study participants by gender, age group and education is presented in Table 1. Lithuanian teachers who participated in the survey stand out for their age: $40.8 \%$ are 50-59 years old. Finnish teachers are distinguished by their education, with the vast majority having a Master's degree and, in addition, almost a third of the Finnish teachers participating in the survey were male. 
Table 1

Descriptive Statistics of the Socio-Demographic Characteristics of Teachers

\begin{tabular}{llcccc}
\hline & & $\begin{array}{c}\text { Estonia } \\
(\mathrm{N}=3083)\end{array}$ & $\begin{array}{c}\text { Finland } \\
(\mathrm{N}=2851)\end{array}$ & $\begin{array}{c}\text { Latvia } \\
(\mathrm{N}=2315)\end{array}$ & $\begin{array}{c}\text { Lithuania } \\
(\mathrm{N}=3759)\end{array}$ \\
\hline \multirow{3}{*}{ Gender } & Female & 82.5 & 69.6 & 88 & 84.3 \\
\cline { 2 - 6 } & Male & 17.5 & 30.4 & 12 & 15.7 \\
\cline { 2 - 6 } & Under 29 & 7 & 6.7 & 7.8 & 2.7 \\
\cline { 2 - 6 } & $30-39$ & 15.5 & 25.5 & 13.8 & 13.9 \\
\cline { 2 - 6 } & $40-49$ & 23.2 & 32.1 & 27.3 & 27.3 \\
\cline { 2 - 6 } & $50-59$ & 32.7 & 28.2 & 33.7 & 40.8 \\
\hline \multirow{2}{*}{$\begin{array}{l}\text { Highest level of } \\
\text { formal education }\end{array}$} & Below ISCED level 6 & 6.5 & 2.5 & 17.4 & 15.3 \\
\cline { 2 - 6 } & ISCED level 6 & 22.1 & 5.8 & 33.1 & 6.2 \\
\cline { 2 - 6 } & ISCED level 7 & 70.7 & 90.4 & 63.5 & 35.9 \\
\cline { 2 - 6 } & ISCED level 8 & 0.7 & 1.3 & 0.4 & 0.6 \\
\hline
\end{tabular}

The distribution according to teaching experience of the teachers participating in TALIS 2018 is shown in Table 2. More than half of the teachers from Estonia, Latvia and Lithuania have more than 20 years of experience in teaching, while more than half of the teachers from Finland have 6 to 20 years of experience in teaching.

Table 2

Descriptive Statistics of Teaching Experience, by Country

\begin{tabular}{lccccccc}
\hline & Mean & $\begin{array}{c}\text { Std. } \\
\text { Deviation }\end{array}$ & Min & Max & $\begin{array}{c}\text { Less than or equal } \\
\text { to 5 years }\end{array}$ & $\begin{array}{c}6 \text { to 20 } \\
\text { years }\end{array}$ & $\begin{array}{c}\text { More than } \\
\text { 20 years }\end{array}$ \\
\hline Estonia & 22.63 & 12.788 & 1 & 58 & $12.9 \%$ & $31.6 \%$ & $55.5 \%$ \\
\hline Finland & 15.94 & 9.428 & 1 & 50 & $16.1 \%$ & $52.5 \%$ & $31.4 \%$ \\
\hline Latvia & 23.74 & 11.987 & 1 & 58 & $10.3 \%$ & $28.6 \%$ & $61.2 \%$ \\
\hline Lithuania & 24.49 & 10.281 & 1 & 54 & $4.5 \%$ & $29.7 \%$ & $65.8 \%$ \\
\hline
\end{tabular}

\section{Instruments}

The questionnaire for teachers participating in TALIS 2018 was composed of 58 questions related to the current work of teachers, teaching and feedback about teaching, school climate and job satisfaction, professional development and teacher mobility (OECD, 2018). Questions related to teacher professional development and its impact on teaching practice were selected from the questionnaire for use in this article:

- TQ22 During the last 12 months, did you participate in any of the following professional development activities?

- TQ25 Thinking of all of your professional development activities during the last 12 months, did any of these have a positive impact on your teaching practice?

- TQ26 Thinking of the professional development activity that had the greatest positive impact on your teaching during the last 12 months, did it have any of the following characteristics?

These three questions offered a dichotomous choice: yes (1) and no (2). 
The following statements were also selected, revealing the attitude of teachers to the co-operation factor and its characteristics (forms and frequency):

- TQ33a How often do you teach jointly as a team in the same class?

- TQ33b How often do you observe other teachers' classes and provide feedback?

- TQ33d How often do you exchange teaching materials with colleagues?

- TQ33e How often do you engage in discussions about the learning development of specific students?

- TQ33f How often do you work with other teachers in this school to ensure common standards in evaluations for assessing student progress?

- TQ33h How often do you take part in collaborative professional learning?

For each item, teachers rated the extent to which they agreed with each item on a 6-point scale ranging from 1 (never) to 6 (once a week or more).

\section{Data Analysis}

The statistical analyses were performed using IBM SPSS Statistics 22.0. Frequency and percentage values were calculated to determine the demographic characteristics of teachers (gender, age group, highest level of formal education, and total years of teaching experience). For research data analysis, Pearson's chi-squared test and ANOVA were used to find differences among the teachers of different countries. Statistical significance was set at $\mathrm{p}<0.05$ for all tests.

\section{Results}

Overview of teacher professional development activities. Looking at the results of teacher professional development according to their chosen forms of learning (Table 3), it can be seen that teachers from all four countries choose ways of developing organizational partnerships (e.g., learning networks) and small groups (e.g., courses) or individual (e.g., reading literature). The absolute majority of teachers took part in seminars/courses during the 12 months prior to the survey, i.e., they chose a traditional way of learning. It is noteworthy that younger teachers (under 29) in Lithuania participate somewhat more actively in such professional development activities than in other countries (Estonia $85.8 \%$; Finland $-63.3 \%$; Latvia $-88.8 \%$; Lithuania $-92.2 \%$ ). It was also found that in all age groups, there were fewer teachers from Finland who attended seminars or courses than teachers from other countries. The second most popular form of teacher professional development in all countries is reading professional literature. The number of Estonian and Lithuanian teachers who learned in this way was relatively larger, while the number of Finnish teachers was relatively smaller. Looking at the number of teachers involved in teacher networks created specifically for teacher professional development, there is again a similar trend: more teachers from Estonia and Lithuania than from Latvia and Finland indicated this form of learning. Latvian teachers are distinguished for their active participation in educational conferences $(71.5 \%)$, while slightly more than half of Lithuanian and Estonian teachers and only one-third of Finnish teachers did so. Observation of colleagues and/or their work and coaching, visits to other schools as professional development activities were noted by more teachers in Latvia and Lithuania. 
Also noteworthy is the extremely low number of Finnish teachers who chose this form of learning $(14.7 \%)$. Less than half of the teachers from all four countries participated in other professional development activities (online courses/seminars, observation visits, formal qualification programs).

Table 3

Descriptive and Non-Parametric Statistics on Participation in Professional Development Activities, by Country

\begin{tabular}{|c|c|c|c|c|c|}
\hline & $\begin{array}{c}\text { Estonia } \\
(\mathrm{N}=3004)\end{array}$ & $\begin{array}{c}\text { Finland } \\
(\mathrm{N}=2851)\end{array}$ & $\begin{array}{c}\text { Latvia } \\
(\mathrm{N}=2315)\end{array}$ & $\begin{array}{l}\text { Lithuania } \\
(\mathrm{N}=3759)\end{array}$ & $\begin{array}{l}\text { Chi-squared } \\
\text { test }\end{array}$ \\
\hline $\begin{array}{l}\text { Courses / seminars attended } \\
\text { in person }\end{array}$ & 89.1 & 68 & 95.4 & 97 & $\begin{array}{c}\chi^{2}=1451.220 \\
\mathrm{p}<0.0001\end{array}$ \\
\hline $\begin{array}{l}\text { Reading professional litera- } \\
\text { ture }\end{array}$ & 90.3 & 75.1 & 81.5 & 94 & $\begin{aligned} \chi^{2} & =568.573 \\
p & <0.0001\end{aligned}$ \\
\hline $\begin{array}{l}\text { Participation in a network } \\
\text { of teachers formed specifi- } \\
\text { cally for the professional } \\
\text { development of teachers }\end{array}$ & 58.6 & 34.3 & 39.4 & 55.6 & $\begin{array}{c}\chi^{2}=496.341 \\
p<0.0001\end{array}$ \\
\hline $\begin{array}{l}\text { Educational conferences } \\
\text { where teachers and/or } \\
\text { researchers present their } \\
\text { research or discuss educa- } \\
\text { tional issues }\end{array}$ & 53.2 & 35.1 & 71.5 & 59.7 & $\begin{array}{c}\chi^{2}=737.618 \\
p<0.0001\end{array}$ \\
\hline $\begin{array}{l}\text { Peer and/or self-observation } \\
\text { and coaching as part of a } \\
\text { formal school arrangement }\end{array}$ & 51.3 & 14.7 & 61.5 & 69.1 & $\begin{array}{c}\chi^{2}=2070.554 \\
p<0.0001\end{array}$ \\
\hline $\begin{array}{l}\text { Observation visits to other } \\
\text { schools }\end{array}$ & 41.4 & 31.4 & 58.6 & 63.3 & $\begin{aligned} \chi^{2} & =807.259 \\
p & <0.0001\end{aligned}$ \\
\hline Online courses / seminars & 39.9 & 22.6 & 29.9 & 46.7 & $\begin{aligned} \chi^{2} & =461.093 \\
p & <0.0001\end{aligned}$ \\
\hline $\begin{array}{l}\text { Observation visits to busi- } \\
\text { ness premises, public orga- } \\
\text { nizations or non-govern- } \\
\text { mental organizations }\end{array}$ & 22.1 & 25.6 & 31 & 36.3 & NS \\
\hline $\begin{array}{l}\text { Formal qualification } \\
\text { program }\end{array}$ & 11.7 & 11 & 18.3 & 18.3 & $\begin{aligned} \chi^{2} & =113.723 \\
p & <0.0001\end{aligned}$ \\
\hline
\end{tabular}

Note: NS - no statistically significant difference.

Teacher professional development through colaboration. Professional colaboration among teachers is an essential precondition for the sustainable professional development of teachers at school. Table 4 shows how often there is colaboration from the point of view of those teachers who claimed that participation in professional development activities had a positive impact on their teaching practices. Different forms of collaborative learning are presented according to the distribution in the TALIS 2018 based on the nature of interaction among teachers (OECD, 2020). The first form: professional collaboration group activities imply a deeper level of co-operation among teachers and a high degree of interdependence among them; the second form: exchange and co-ordination for teaching includes simple exchanges or co-ordination between teachers (ibid). 
Analyzing the presented ANOVA test results, it is seen that Finnish teachers more often than those of the other three countries teach jointly as a team in the same class $(\mathrm{F}=198.145, \mathrm{p}<0.0001)$, exchange teaching materials with colleagues $(\mathrm{F}=58.816$, $\mathrm{p}<0.0001$ ), and engage in discussions about the learning development of specific students $(\mathrm{F}=615.053, \mathrm{p}<0.0001)$. Latvian teachers more often observe other teachers' classes and provide feedback $(\mathrm{F}=473.063, \mathrm{p}<0.0001)$, while Estonian teachers take part in collaborative professional learning $(\mathrm{F}=179.510, \mathrm{p}<0.0001)$. Moreover, it turned out that Estonian and Latvian teachers more often than Finnish and Lithuanian teachers work with other teachers in school to ensure common standards in evaluations for assessing student progress $(\mathrm{F}=151.155, \mathrm{p}<0.0001)$. The teachers of all four countries indicate as having an effect on their teaching practice the different forms of colaboration, which are related to a deeper level of co-operation as well as to simple exchange and coordination for teaching.

Table 4

ANOVA Test Results for Different Collaborative Learning Forms, by Country

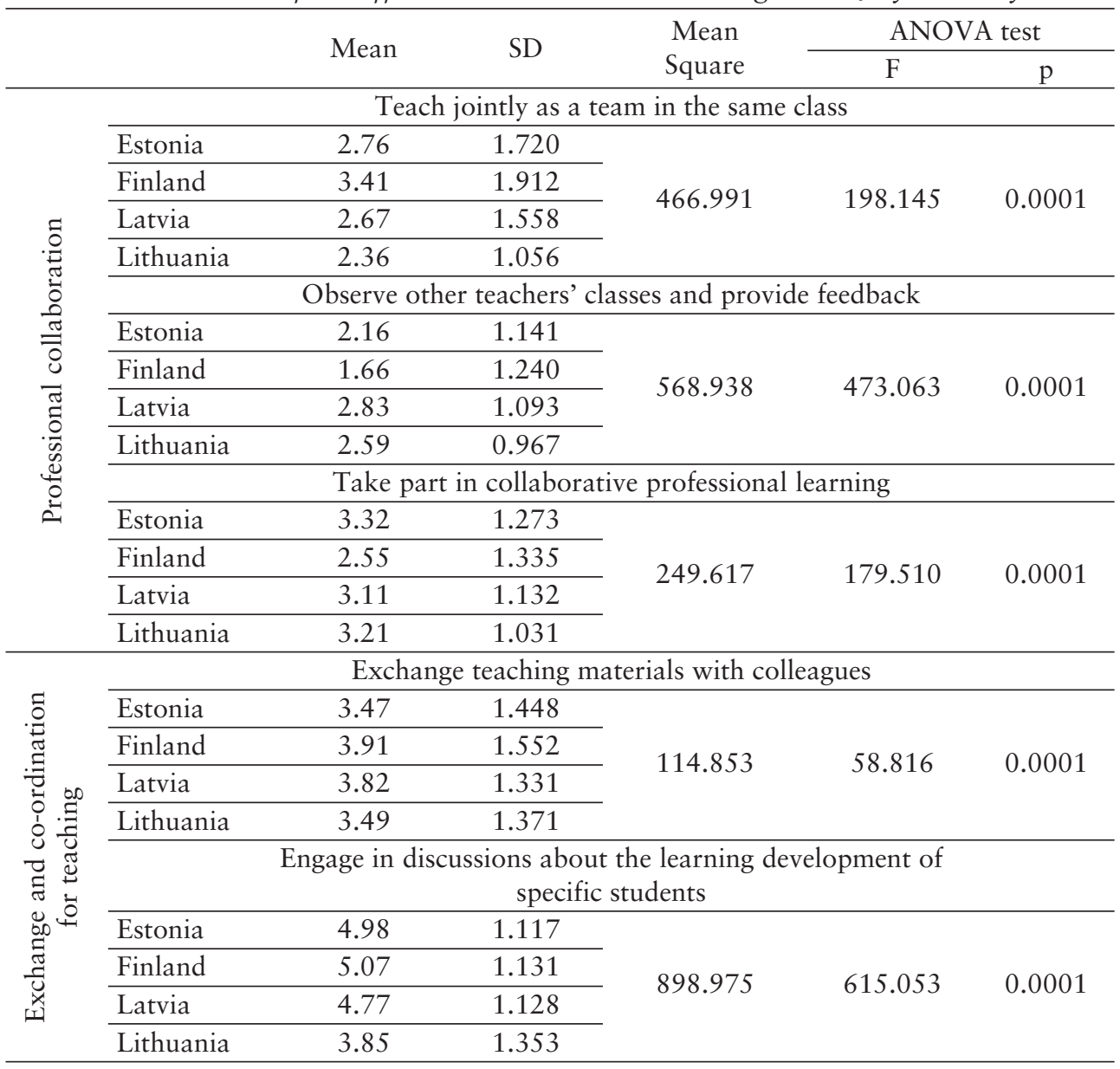


Continuation of Table 4

\begin{tabular}{|c|c|c|c|c|c|c|}
\hline \multirow{5}{*}{ 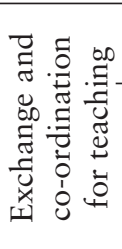 } & \multicolumn{6}{|c|}{$\begin{array}{l}\text { Work with other teachers in school to ensure common standards } \\
\text { in evaluations for assessing student progress }\end{array}$} \\
\hline & Estonia & 4.02 & 1.440 & \multirow{4}{*}{290.806} & \multirow{4}{*}{151.155} & \multirow{4}{*}{0.0001} \\
\hline & Finland & 3.81 & 1.551 & & & \\
\hline & Latvia & 4.01 & 1.321 & & & \\
\hline & Lithuania & 3.33 & 1.278 & & & \\
\hline
\end{tabular}

Note. Response options: 1 - never; 2 - once a year or less; 3-2-4 times a year; 4-5-10 times a year; 5-1-3 times a month; 6 - once a week or more.

The survey results presented in Table 4 show that, according to teachers, collaborative learning activities take place on average several times a year. However, it is important to analyze these answers in more detail and to draw attention to cases where teachers say that activities take place at least once a month or more frequently. It is in this case that sustainable professional development based on collaborative learning takes place at school. Summarizing the results of the survey (Table 5), it has become clear that more teachers from Finland, Estonia and Latvia than from Lithuania participate in collaborative learning activities at school.

Table 5

Collegial Cooperation Activities, Once A Month or More Often, from the Point of View of Teachers (\%)

\begin{tabular}{|c|c|c|c|c|c|c|}
\hline & & $\begin{array}{c}\text { Estonia } \\
(\mathrm{N}=2164)\end{array}$ & $\begin{array}{c}\text { Finland } \\
(\mathrm{N}=2051)\end{array}$ & $\begin{array}{c}\text { Latvia } \\
(\mathrm{N}=1956)\end{array}$ & $\begin{array}{l}\text { Lithuania } \\
(\mathrm{N}=3309)\end{array}$ & $\begin{array}{c}\text { Chi-squared } \\
\text { test }\end{array}$ \\
\hline \multirow{3}{*}{ 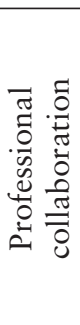 } & $\begin{array}{l}\text { Teach jointly as a team } \\
\text { in the same class }\end{array}$ & 20.8 & 34.8 & 16.5 & 5 & $\begin{array}{c}\chi^{2}=1300.987 \\
p<0.0001\end{array}$ \\
\hline & $\begin{array}{l}\text { Observe other teachers' } \\
\text { classes and provide } \\
\text { feedback }\end{array}$ & 5.5 & 6.3 & 9.3 & 4.2 & $\begin{array}{c}\chi^{2}=2803.766 \\
p<0.0001\end{array}$ \\
\hline & $\begin{array}{l}\text { Take part in collabo- } \\
\text { rative professional } \\
\text { learning }\end{array}$ & 20.7 & 9.7 & 13.4 & 11.3 & $\begin{array}{c}\chi^{2}=1438.399 \\
p<0.0001\end{array}$ \\
\hline \multirow{3}{*}{ 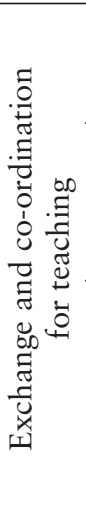 } & $\begin{array}{l}\text { Exchange teaching } \\
\text { materials with col- } \\
\text { leagues }\end{array}$ & 29.1 & 42.6 & 36 & 26.5 & $\begin{array}{c}\chi^{2}=327.373 \\
p<0.0001\end{array}$ \\
\hline & $\begin{array}{l}\text { Engage in discussions } \\
\text { about the learning } \\
\text { development of specific } \\
\text { students }\end{array}$ & 73.3 & 75.2 & 65.3 & 35.2 & $\begin{array}{c}\chi^{2}=1455.123 \\
p<0.0001\end{array}$ \\
\hline & $\begin{array}{l}\text { Work with other } \\
\text { teachers in school to } \\
\text { ensure common stan- } \\
\text { dards in evaluations for } \\
\text { assessing student } \\
\text { progress }\end{array}$ & 43.6 & 39.5 & 41.2 & 20.6 & $\begin{array}{c}\chi^{2}=652.294 \\
p<0.0001\end{array}$ \\
\hline
\end{tabular}

The factor of teacher learning at school and its characteristics. The next point to be analyzed is what characterizes the professional development that took place in the 
environment closest to teachers (school) and was sustainable, i.e., it had a positive impact on teaching practices. Table 6 shows the number of teachers participating in the TALIS 2018 and the characteristics of the courses/seminars taking place at school. Summarizing the results of the survey, it was clear that most teachers emphasized that seminars/ courses gave them the opportunity to learn actively (mainly Estonian teachers) and through colaboration. It should be noted that more Estonian teachers than those of the other three countries participated in long-term seminars/courses. More teachers of younger age (under 30) chose this professional development method at their school, especially in Estonia $\left(56 \% ; \chi^{2}=7.810, \mathrm{p}<0.05\right)$ and in Lithuania $\left(46 \% ; \chi^{2}=25.702, \mathrm{p}<0.0001\right)$. It should be noted that an especially large number of Lithuanian teachers $(\mathrm{N}=1984)$ indicated that they attended courses/seminars, but only $20.1 \%$ of them noted that such professional development activities were long-term.

Table 6

Characteristics of Seminars/Courses that had a Positive Impact on Teaching Practices and took Place in Schools, from the Point of View of Teachers (\%)

\begin{tabular}{lccccc}
\hline \multicolumn{1}{c}{ Characteristics } & $\begin{array}{c}\text { Estonia } \\
(\mathrm{N}=1013)\end{array}$ & $\begin{array}{c}\text { Finland } \\
(\mathrm{N}=446)\end{array}$ & $\begin{array}{c}\text { Latvia } \\
(\mathrm{N}=819)\end{array}$ & $\begin{array}{c}\text { Lithuania } \\
(\mathrm{N}=1984)\end{array}$ & $\begin{array}{c}\text { Chi-squared } \\
\text { test }\end{array}$ \\
\hline Active learning & 83.4 & 78 & 81 & 68.9 & $\begin{array}{c}\chi^{2}=96.090 \\
\mathrm{p}<0.0001\end{array}$ \\
\hline Collaborative learning & 83.5 & 79.4 & 77.2 & 84.5 & $\mathrm{NS}$ \\
\hline Long-term learning & 46.9 & 22.9 & 39 & 20.1 & $\begin{array}{c}\chi^{2}=269.892 \\
\mathrm{p}<0.0001\end{array}$ \\
\hline
\end{tabular}

Note: NS - no statistically significant difference.

The characteristics of the peer and/or self-observation and coaching that took place at school and had a positive impact on teaching practice are shown in Table 7. Most teachers from all four countries highlighted the opportunity to learn actively in this way. The opinion of teachers from three countries (Estonia, Latvia and Finland) did not depend on the length of service or age, while the sample of teachers from Lithuania showed statistically significant differences. Peer and/or self-observation and coaching provided opportunities to learn actively more for young teachers $(80.9 \%$, length of service less than 5 years) than for those who have worked longer than 20 years $(68 \%$; $\left.\chi^{2}=10.646, \mathrm{p}<0.01\right)$. In addition, most teachers, irrespective of their length of service and age, suggested that participation in such professional development activities enabled them to learn through cooperation. More teachers from Estonia (49.9\%) and from Latvia $(42.7 \%)$ than from Finland and Lithuania indicated that they participated in long-term peer and/or self-observation and coaching. It was again established that although a significant number of Lithuanian teachers participated in such professional development activities, only $20 \%$ indicated that such activities were long-term, and again long-term learning was more characteristic of younger teachers $\left(\chi^{2}=7.340, p<0.05\right)$. 
Table 7

Characteristics of Peer and/or Self-Observation and Coaching which had a Positive Impact on Teaching Practices and took Place at School, from the Point of View of Teachers (\%)

\begin{tabular}{lccccc}
\hline \multicolumn{1}{c}{ Characteristics } & $\begin{array}{c}\text { Estonia } \\
(\mathrm{N}=672)\end{array}$ & $\begin{array}{c}\text { Finland } \\
(\mathrm{N}=142)\end{array}$ & $\begin{array}{c}\text { Latvia } \\
(\mathrm{N}=567)\end{array}$ & $\begin{array}{c}\text { Lithuania } \\
(\mathrm{N}=1530)\end{array}$ & $\begin{array}{c}\text { Chi-squared } \\
\text { test }\end{array}$ \\
\hline Active learning & 85.4 & 78.2 & 82.2 & 70.8 & $\mathrm{NS}$ \\
\hline Collaborative learning & 86.3 & 81 & 80.6 & 87.1 & $\mathrm{NS}$ \\
\hline Long-term learning & 49.9 & 26.8 & 42.7 & 20 & $\begin{array}{c}\chi^{2}=233.156 \\
\mathrm{p}<0.0001\end{array}$ \\
\hline
\end{tabular}

Note: NS - no statistically significant difference.

The typical positive impact of school visits on teaching practices is shown in Table 8 . The majority of teachers in all four countries stressed that this professional development activity enabled them to learn through active and collaborative learning. Among Estonian teachers, the possibility of active learning was more often identified by those teachers whose length of service was 6-20 years $\left(\chi^{2}=11.886, \mathrm{p}<0.01\right)$, and among teachers in Lithuania who had worked for not longer than 5 years $\left(\chi^{2}=14.440, p<0.001\right)$. The percentage of Estonian teachers who participated in long-term school visits was significantly higher than in the other three countries $\left(\chi^{2}=267.164, \mathrm{p}<0.0001\right)$. Lithuanian teachers stand out for their activeness: as many as 2,151 teachers indicated that they participated in visits to other schools. However, of these, only $19.4 \%$ took part in longterm visits, more often younger $\left(44.4 \% ; \chi^{2}=14.552, \mathrm{p}<0.001\right)$ and having up to 5 years of service $\left(32.4 \% ; \chi^{2}=20.316, \mathrm{p}<0.0001\right)$.

Table 8

Characteristics of School Visits which have had a Positive Impact on Teaching Practice, from the Point of View of Teachers (\%)

\begin{tabular}{lccccc}
\hline \multicolumn{1}{c}{ Characteristics } & $\begin{array}{c}\text { Estonia } \\
(\mathrm{N}=993)\end{array}$ & $\begin{array}{c}\text { Finland } \\
(\mathrm{N}=736)\end{array}$ & $\begin{array}{c}\text { Latvia } \\
(\mathrm{N}=1200)\end{array}$ & $\begin{array}{c}\text { Lithuania } \\
(\mathrm{N}=2151)\end{array}$ & $\begin{array}{c}\text { Chi-squared } \\
\text { test }\end{array}$ \\
\hline Active learning & 86.7 & 79.1 & 81.9 & 71.4 & $\mathrm{NS}$ \\
\hline Collaborative learning & 84.1 & 78.9 & 77.1 & 85.7 & $\mathrm{NS}$ \\
\hline Long-term learning & 45.9 & 21.2 & 32.5 & 19.4 & $\begin{array}{c}\chi^{2}=267.164 \\
\mathrm{p}<0.0001\end{array}$ \\
\hline
\end{tabular}

Note: NS - no statistically significant difference.

Summarizing teacher professional development activities with a positive impact on teaching practice and taking place at school, it is noted that active and collaborative learning predominates, although such professional development is not always long-term.

\section{Discussion}

Discussing the results, it is important to note that there is no 'one size fits all' approach to professional learning (Campbell, 2019). The aim of this article was to reveal similarities and differences in the sustainable professional development of teachers in four Baltic countries and to describe the characteristics of teacher professional development in each country. 
Teachers from all of the studied countries are actively involved in various professional development activities. However, courses and seminars predominate, along with reading of professional literature; formal qualification programs are the least acceptable method of professional development. The results of this study reflect the general trends in traditional teacher learning in Europe and the world. Another growing trend is the inclination of young teachers towards long-term professional development.

Countries differ most according to forms of collaborative learning; they are more characteristic of teachers in Finland, Estonia and Latvia, while in Lithuania they are more characteristic of younger teachers. A more detailed review of the professional development of teachers in the four countries reveals more subtle differences and similarities.

Compared to the neighboring three countries (Latvia, Estonia and Finland), Lithuanian teachers participate the most in professional development activities (see Table 3), but we certainly cannot say that this will be linked to a higher level of achievements by school learners in Lithuania. Finnish teachers participate the least among all countries examined and this difference is significant. On the one hand, this may be explained by the fact that most Finnish teachers have a Master's degree. According to Tonga and co-authors (Tonga et al., 2019), high standards are set for the teaching profession (e.g., rigorous pre-selection and assessment of teacher candidates, minimum of a Bachelor's degree) in countries with high levels of school learner achievement (in this case, in Estonia and in Finland). On the other hand, Li and Dervin (2018) argue that the forms of non-formal learning of Finnish teachers - cooperation and mutual learning - can take place of formal professional development. Our analysis also shows that teachers in Finland (together with Estonian and Latvian teachers) are more likely to participate in collaborative learning activities than Lithuanian educators. Thus, Finland's teachers seem to participate less in formal professional development activities, but their learning can be of high quality and their professional development is sustainable.

Sarv (2014) notes that in Estonia, a teacher is an active learner who plans, manages and evaluates his/her learning and professional growth. As a teacher's life-long learning takes place in a specific working environment, teacher professional development is a collegial process influenced by colleagues, school leaders, parents and a community of teachers in a broad sense. The Estonian Teacher Education Strategy (2012) also emphasizes collegial learning by encouraging and supporting professional learning communities, while the results of study of their activities and best practices need to be shared among colleagues in their region or across the country. Our comparative analysis of the four countries also showed that Estonian teachers, more than in the other countries, took part in collaborative professional learning, long-term seminars/courses and long-term peer and/or self-observation and coaching. It is assumed that such sustainable learning by Estonian teachers can be one of the factors that creates teacher working culture and an educational system where practically every member of the staff is able to perform their work well, which is likely to influence the good learning achievements of Estonian school learnerss. According to Sarv (2014), her country's school is an active learning organization that participates in a teacher's personal, professional and collegial/community growth.

Discussing the professional development experience of Latvian teachers, it should be noted that Latvian teachers, more often than teachers from the other three countries, observe other teachers' classes and provide feedback, and, together with Estonian teachers 
and more often than Lithuanian and Finnish teachers, work with other teachers at school to ensure common standards in evaluations for assessing student progress and participate in long-term peer and/or self-observation and coaching. A review of the scientific literature reveals a certain focus by Latvian teachers on classroom action research that becomes a bridge between theory and practice in contextual teacher development (Meesuk, Sramoon, \& Wongrugsa, 2020; Volkinsteine \& Namsone, 2016) that promises participants a new perspective and an opportunity to explore a phenomenon in a broader cooperation and partnership unit (Salite et al., 2016). Thus, a certain common model of teachers' learning in a team (teacher learning-team model) puts more emphasis on practical issues related to classroom activities (Iliško, Ignatjeva, \& Mičule, 2010), which is confirmed by our results.

Real excellence grows through learning from practical activities, when decisions are based on such learning, which influences the quality of education and learner outcomes. Observation of colleagues and/or their work and coaching, and visits to other schools as professional development activities, were noted by many Lithuanian teachers, and most teachers according to the research data took part in collaborative professional learning. The study shows that more active and long-term learning forms are characteristic of young teachers. We would dare say that the attitude of Lithuanian teachers towards professional development is gradually changing. The results of research performed more than five years ago (Valuckiene et al., 2015) showed that on their own initiative Lithuanian teachers rarely looked for solutions to improve school activities, actively discussed, presented proposals, and undertook measures to implement such proposals themselves. Based on the results of this research, it is thought that teachers in Lithuania are perhaps beginning to see professional development as a long-term, cooperative, reflexive process taking place in the context of a particular school community.

\section{Implications for Future Research}

It must be recognized that teacher professional development is a large space for scientific research because, as already mentioned, this field still lacks conceptual foundations. Dromantiené, Indrašiené, Merfeldaite and Prakapas (2013) postulate that researchers in education sciences do not conduct targeted studies of Lithuanian teacher qualification improvement processes and studies on the impact of in-service training on the quality of education. Current studies focus only on solitary, quite specialized problematic questions, rarely and indirectly linking them with teacher professional development. Systematic research is therefore needed to provide a conceptual basis for professional development processes and for measuring their success, reflecting all of which through the perspective of sustainable development.

The results of this study revealed similarities and differences among teacher professional development in four countries, which, on the one hand, are somewhat surprising given the common past of the three Baltic countries (Lithuania, Latvia and Estonia) and the fact that their educational systems were quite similar. On the other hand, we have to recognize that countries do not have their own uniform, refined educational models with a clear direction of development, e.g., Latvia and Lithuania are moving closer to a liberal Anglo-Saxon model, while Estonia in certain respects shows greater similarity to Finland (Želvys, Jakaitiene, \& Stumbriené, 2017). This calls for in-depth research into national educational developments and national educational policy, which could possibly 
explain the qualitative differences among the educational systems of the countries. The use of international coordinated teams of researchers would be useful for such research.

A cautious assumption based on the found statistical differences, that collaborative and long-term teacher learning has an impact on school learner performance, should be verified by separate research, with particular reference to impact measurement tools. Such research (particularly longitudinal studies) would most clearly ground the effectiveness of teacher professional development. According to Hanushek (2011), research unambiguously confirms the importance of a teacher as a factor, but it is very difficult to identify the characteristics of the teacher's learning that are reliably linked to school learner's results. However, even if we do not see a clear link between teacher professional development and school learner's results, we would still think it is very important to discuss teacher professional development (making use of contributions from other fields of science). The contemporary theory of teaching and learning is complemented by data from other sciences, such as the recent debate on educational neuroscience as an area of science that combines education (how teaching affects learning) and neuroscience (the understanding of how the nervous system works) (Mayer, 2017).

We believe that the concept of learning emphasized by Education for Sustainable Development, namely, active, learner-oriented, partnership-based, reflexive learning (Salite, 2008), should also become the basis for research on teacher professional development, without forgetting a postulate of sustainable development: have patience while awaiting results.

\section{Acknowledgements}

Elaboraton of the article has been funded by the international project "Comprehensive University Development in the Context of Universities Network Restructurisation" (No. 09.3.1-ESFA-V-738-02-0001).

\section{References}

Basma, B., \& Savage, R. (2018). Teacher professional development and student literacy growth: A systematic review and meta-analysis. Educational Psychology Review, 30(2), 457-481. Retrieved from https://doi.org/10.1007/s10648-017-9416-4

Campbell, C. (2019). Perspectives and evidence on effective CPD from Canada. In Shutt, C., \& Harrison, S. (Eds), Teacher CPD: International trends, opportunities and challenges (pp. 68-74). London: Chartered College of Teaching. Retrieved from https://chartered.college/international-teacher-cpd-report/

Cordingley, P. (2019). Collaborative engagement in and with research: A central part of the CPD landscape. In Shutt, C., \& Harrison, S. (Eds), Teacher CPD: International trends, opportunities and challenges (pp. 138-143). London: Chartered College of Teaching. Retrieved from https://chartered.college/international-teacher-cpd-report/

Darling-Hammond, L., Hyler, M. E., \& Gardner, M. (2017). Effective teacher professional development. Palo Alto: Learning Policy Institute.

Dromantienè, L., Indrašienè, V., Merfeldaitè, O., \& Prakapas, R. (2013). Teachers’

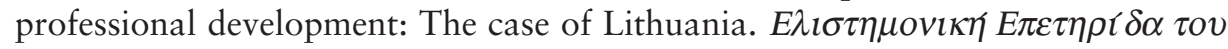

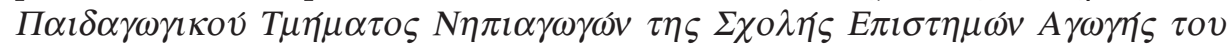
$\Pi \alpha v \varepsilon \pi \iota \sigma \tau \eta \mu \iota$ ov I $\omega \alpha v v \iota v \omega v$ [Journal of Research in Education and Training], 6, 202-215. Retrieved from https://doi.org/10.12681/jret.760 
Estonian Ministry of Education and Research (n.d). The Estonian Teacher Education Strategy for 2009-2013. Retrieved from www.hm.ee/index.php?0\&popup= download\&id=10278

Fletcher-Wood, H., \& Zuccollo, J. (2020). The effects of high-quality professional development on teachers and students. Retrieved from https:/epi.org.uk/ publications-and-research/effects-high-quality-professional-development/

Guskey, Th. R. (2009). Closing the knowledge gap on effective professional development. Educational Horizons, 87(4), 224-233. Retrieved from https:/eric.ed.gov/?id= EJ849021

Guskey, Th. R., \& Sparks, D. (2002). Linking professional development to improvements in student learning. Paper presented at the Annual Meeting of the American Educational Research Association. Retrieved from https://eric.ed.gov/?id=ED464112

Hanushek, E. A. (2011). The economic value of higher teacher quality. Economics of Education Review, 30, 466-479. Retrieved from https://doi.org/10.1016/j. econedurev.2010.12.006

Hargreaves, A., \& Fink, D. (2006). Sustainable leadership. San Francisco: Jossey-Bass. Hargreaves, A., \& Fullan, M. (2012). Professional capital: Transforming teaching in every school. New York: Teachers College Press.

Harrison, C., Hofstein, A., Eylon, B., \& Simon, S. (2006). Evidence based professional development of science teachers in two countries. International Journal of Science Education, 30(5), 577-591. Retrieved from https://doi.org/10.1080/09500690 701854832

Iliško, D., Ignatjeva, S., \& Mičule, I. (2010). Teachers as researchers: Bringing teachers' voice to the educational landscape. Journal of Teacher Education for Sustainability, 12(1), 51-65. Retrieved from https://doi.org/10.2478/v10099-009-0046-x

Jensen, B., Sonnemann, J., Roberts-Hull, K., \& Hunter, A. (2016). Beyond PD: Teacher professional learning in high-performing systems. Washington, DC: National Center on Education and the Economy. Retrieved from https://www.ncee.org/wp-content/ uploads/2015/08/BeyondPDWeb.pdf

Li, Y., \& Dervin, F. (2018). Continuing professional development of teachers in Finland. Cham: Palgrave Macmillan.

Makovec, D. (2018). The teacher's role and professional development. International Journal of Cognitive Research in Science, Engineering and Education, 6(2), 33-45. Retrieved from https://doi.org/10.5937/ijcrsee1802033M

Mayer, R. E. (2017). How can brain research inform academic learning and instruction? Educational Psychology Review, 29(4), 835-846. Retrieved from https://doi.org/ 10.1007/s10648-016-9391-1

Meesuk, P., Sramoon, B., \& Wongrugsa, A. (2020). Classroom action research-based instruction: The sustainable teacher professional development strategy. Journal of Teacher Education for Sustainability, 22(1), 98-110.

OECD (2018). Teaching and learning international survey (TALIS): Teacher questionnaire. Retrieved from http://www.oecd.org/education/school/TALIS-2018-MSTeacher-Questionnaire-ENG.pdf

OECD (2020). TALIS 2018 results (Volume II): Teachers and school leaders as valued professionals. TALIS, OECD Publishing, Paris. Retrieved from https://doi.org/ $10.1787 / 19$ cf08df-en 
Postholm, M. P. (2012). Teachers' professional development: A theoretical review. Educational Research, 54(4), 405-429. Retrieved from https://doi.org/10.1080/00131881. 2012.734725

Postholm, M. P. (2016). Collaboration between teacher educators and schools to enhance development. European Journal of Teacher Education, 39(4), 452-470. Retrieved from https://doi.org/10.1080/02619768.2016.1225717

Salite, I. (2008). Educational action research for sustainability: Constructing a vision for the future in teacher education. Journal of Teacher Education for Sustainability, 10, 5-16.

Salīte, I., Drelinga, E., Iliško, D., Oḷehnoviča, E., \& Zariṇa, S. (2016). Sustainability from the transdisciplinary perspective: An action research strategy for continuing education program development. Journal of Teacher Education for Sustainability, $18(2), 135-152$.

Sarv, E. S. (2014). A status paper on school teacher training in Estonia. Journal of International Forum of Educational Research, 1(2), 106-158.

Silova, I., Moyer, A., Webster, C., \& McAllister, S. (2010). Re-conceptualizing professional development of teacher educators in post-Soviet Latvia. Professional Development in Education, 36(1-2), 357-371. Retrieved from https://doi.org/10.1080/ 19415250903457596

Sims, S., \& Fletcher-Wood, H. (2020). Identifying the characteristics of effective teacher professional development: A critical review. School Effectiveness and School Improvement, 1-17. Retrieved from https://doi.org/10.1080/09243453.2020.1772841

Sumaryanta, Mardapi, S., Sugiman, \& Herawan, T. (2019). Community-based teacher training: Transformation of sustainable teacher empowerment strategy in Indonesia. Journal of Teacher Education for Sustainability, 21(1), 48-66.

Thurlings, M. C. G., \& den Brok, P. J. (2017). Learning outcomes of teacher professional development activities: A meta-study. Educational Review, 69(5), 554-576. Retrieved from https://doi.org/10.1080/00131911.2017.1281226

Tonga, F. E., Eryiğit, S., Yalçın, F. A., \& Erden, F. T. (2019). Professional development of teachers in PISA achiever countries: Finland, Estonia, Japan, Singapore, and China. Professional Development in Education, 1-18. Retrieved from https://doi. org/10.1080/19415257.2019.1689521

UNESCO (2015). Education 2030. Incheon declaration and framework for action. Paris: UNESCO. Retrieved from https://unesdoc.unesco.org/ark:/48223/ pf0000245656

UNESCO (2017). Education for sustainable development goals: Learning objectives. Paris: UNESCO. Retrieved from https://unesdoc.unesco.org/ark:/48223/ pf0000247444

UNESCO (2020). Towards inclusion in education: Status, trends, and challenges. The UNESCO Salamanca Statement 25 years on. Paris: UNESCO. Retrieved from https://unesdoc.unesco.org/ark:/48223/pf0000374246

UNESCO International Bureau of Education (2015). Repositioning and reconceptualizing the curriculum for the effective realization of Sustainable Development Goal Four, for holistic development and sustainable ways of living. Discussion paper presented at the World Education Forum, Incheon, Republic of Korea, 19-22 May 2015. Geneva: UNESCO-IBE. Retrieved from https://www.gcedclearinghouse.org/ resources/repositioning-and-reconceptualizing-curriculum-effective-realizationsustainable 
UNESCO International Commission on the Futures of Education (2020). Education in a post-COVID world: Nine ideas for public action. Paris: UNESCO. Retrieved from https://unesdoc.unesco.org/ark:/48223/pf0000373717/PDF/373717eng. pdf.multi

United Nations (2015). Transforming our world: The 2030 Agenda for Sustainable Development. Retrieved from https://sdgs.un.org/2030agenda

United Nations (2020). Policy brief: Education during COVID-19 and beyond. Retrieved from https://unsdg.un.org/resources/policy-brief-education-during-covid-19-andbeyond

Valuckienè, J., Balčiūnas, S., Katiliūtè, E., Simonaitienè, B., \& Stanikūnienè, B. (2015). Lyderyste mokymuisi: teorija ir praktika mokyklos kaitai [Leadership for learning: Theory and practice for school change]. Šiauliai: Titnagas.

Villegas-Reimers, E. (2003). Teacher professional development: An international review of the literature. Paris: International Institute for Educational Planning. Retrieved from https://unesdoc.unesco.org/ark:/48223/pf0000133010

Volkinsteine, J., \& Namsone, D. (2016). Latvian science teacher experience in learning team for Improvement of Inquiry Teaching Practice. In Proceedings of ICERI 2016 Conference (pp. 3911-3920). Retrieved from https:/www.siic.lu.lv/fileadmin/ user_upload/lu_portal/projekti/siic/Publikacijas/VPP_publikacijas/2_Science_ Teacher_Experience_in_Learning_Team_for_Improvement_of_Inquiry_Teaching_ Practice.pdf

Wells, M. (2013). Elements of effective and sustainable professional learning. Professional Development in Education, 40(3), 488-504. Retrieved from https://doi.org/10.1080/ 19415257.2013.838691

Weston, D., \& Hindley, B. (2019). Professional development: Evidence of what works. In Shutt, C., \& Harrison, S. (Eds), Teacher CPD: International trends, opportunities and challenges (pp. 60-67). London, Chartered College of Teaching. Retrieved from https://chartered.college/international-teacher-cpd-report/

Želvys, R., Jakaitienè, A., \& Stumbrienè, D. (2017). Moving towards different educational models of the welfare state: Comparing the education systems of the Baltic countries. Filosofija. Sociologija [Philosophy. Sociology], 28(2), 139-150. Retrieved from http://mokslozurnalai.lmaleidykla.lt/filosofijasociologija/2017/2/7395

Correspondence concerning this paper should be addressed to Agne Brandisauskiene, Associate professor at the Education Academy, Vytautas Magnus University, 58 K. Donelaičio Str., LT-44248, Kaunas, Lithuania. Email: agne.brandisauskiene@vdu.lt 